\title{
German and Russian Political Blogs as Relevant Protest Practice in Context of Modern Society Mediatization
}

\author{
Elena Terentyeva ${ }^{1 *}$, Marina Milovanova ${ }^{1}$, Elena Pavlova ${ }^{2}$, Nina Wendt $^{3}$, and Rumiya \\ Kaderova $^{2}$ \\ ${ }^{1}$ Department of Russian Philology and Journalism, Volgograd State University, 100 University \\ Avenue, Volgograd, 400062, Russian Federation \\ ${ }^{2}$ Department of Foreign Languages, Peoples' Friendship University of Russia (RUDN University), 6 \\ Miklukho-Maklaya Street, Moscow, 117198, Russian Federation \\ ${ }^{3}$ Language and Interpreting Institute Munich (SDI München), 28 Baierbrunner Street, 81379 Munich, \\ Germany
}

\begin{abstract}
The study reveals the multifunctionality which is typical of German and Russian political blogs. Regardless of the language of the blogs, information and evaluation, political and convening, consolidating, agitation and propaganda, presentation and propaganda, and directive functions are among the dominant functions. The paper briefly describes the linguistic means which represent these functions. It shows the discursive hybridity of political blogs which is manifested in combining the features of Internet discourse with elements of political, news, journalistic, and social values discourses (in German political blogs) and political, business, legal, conversational, and artistic discourses (in Russian political blogs). The authors establish the relevant communicative strategies of the addresser (the strategy to justify a "problem", the strategy to support / not support demonstrated evaluation) and the tactics that implement them. The authors also define the topics for discussion which initiate the addressee's protest reaction - these are social issues, international and regional developments, environment and migration crisis in German political blogs and finance and taxes, constitution and government, elections, corruption and officials in Russian political blogs. The paper describes the ways of forming and maintaining convening technologies in the protest practice considered. It considers the features of mediatization of politics and personality in the content analyzed, which are manifested in guiding the political agenda to the needs of the addressee. It also establishes that German and Russian political blogs as a protest practice are characterized by a set of common system and communicative characteristics, a similar strategy and tactic organization, and a different set of problem areas marked with the "threat" index. The results obtained contribute to further development of the provisions of the communicative theory of protest, facilitate the understanding of modern protest forms and attempt to explain how technology, politics and the media sphere are interlinked.
\end{abstract}

\footnotetext{
* Corresponding author:ev terenteva@ volsu.ru
} 


\section{Introduction}

The mediatization of modern society manifesed in the integration of digital media into all social processes including political ones [1, 5-7] creates conditions for the transformation of protest practices which contribute to the implementation of "controlled chaos" technologies. These are aimed at transferring political systems, institutions, regimes and situations to a new state $[2,10,13]$. The combination of protest practices with the processes of mediatization in the modern society encourages researchers to study of the latest formats and mechanisms for organizing collective interactions, consider the processes of changing communication, the emergence of a different communicative experience of subjects, and the formation of a new attitude towards the value and reliability of information $[3,9,15]$. These aspects of research are designed to assess the factors which influence the transformation of protest practices and help further develop algorithms for regulating protest behavior and managing conflict societies.

The subject of the present study is the system and communicative characteristics of German and Russian protest content. The study set out to conduct a comprehensive comparative analysis of contemporary protest in Germany and Russia in the context of the mediatization of society based on the material of political blogs. The study methodology is based on a combination of system and communicative and integrative approaches; on scientific theses on the system and communicative autonomy of protest; on interrelations between the technological and sociocultural, political and media spheres; on the discursive construction of reality and subjects of communication as well as how the phenomenon of mediatization is reflected in modern Internet practices and how it changes thinking and psychology of the subjects of communication $[4,16]$; on the interpretation of protest as a communicative practice of conflict resolution $[11,14]$.

The study material was the content of German political blogs available on the platform https://www.cision.de/top-10-blogs-politik, Wolfgang Prabel's (http://www.prabelsblog.de) and Sarah Wagenknecht's (https://twitter.com/SWagenknecht) popular opposition blogs as well as the content of Russian political blogs available on the platform https://www.livejournal.com/media and the Ekho Moskvy information website, and popular political blogs whose authors are representatives of opposition political movements and platforms (https://varlamov.ru; https://navalny.com).

The final sample size was about 1,000 German and 1,000 Russian posts for the period from 2018 to 2020 .

\section{Political blogs in Germany and Russia: discursive and genre characteristics}

The analysis of the blog content has shown that the blogs are characterized by multifunctionality manifested in the interaction and diffusion of a number of functions that ensure the implementation of purely political goals of the blog authors and at the same time are a means of their public self-presentation through a specific form of creative activity. Thus, in the content of the German and Russian political blogs analyzed, the following functions are distinguished: information, information and evaluative, reflexive, presentation and propaganda, counter-propaganda, political and brending, political and convening, consolidation, and directive functions. The multifunctionality of political blogs determines their polydiscoursivity, which in turn is reflected in the polygenre variety of content. At the same time, it should be noted that the political blog, which is a hypergenre, combines such genres as post, petition, investigative journalism, open letter, appeal, remark, and comment. In addition, these subgenres, in turn, can acquire the features of hybrid genres that have the 
characteristics of several genres, and represent creolized texts. Next, we will look in more detail at some examples that can be considered typical.

\subsection{Polydiscourse and polygenre nature of German blogs}

German blogs are characterized by polydiscursivity, which is manifested in the combination of Internet discourse with elements of political, informational, journalistic, and socially oriented discourses. Political blogs in Germany demonstrate a focus on the current political agenda, agitation and propaganda, and socially significant themes. In addition, they share such common features of the journalistic style as relevance, persistence, evaluation, expressiveness, dynamism, clarity, and thematic diversity. These discursive features are reflected in the genre hybridization of political blogs, determined by a combination of journalistic genre features such as diary, post, comment, investigation, and political appeal. Common features of all blogs as varieties of these genres are the expression of one's own political position, reasonableness, intentionality, convening power, dominance of the addresser in relation to the addressee and mass addressee. In order to illustrate of the theoretical positions stated, we present a post belonging to the popular German blogger V. Prabel which contains features of political and journalistic discourses, as well as signs of genre hybridization (12.09.2020 von Wolfgang Prabel. Zwischenbilanz nach 3.000 Einträgen). The post is a text of a hybrid nature including the elements of a diary which construct the self-image of a politician (Am 13.11.2012 hatte ich den ersten Eintrag auf PB gepostet) with a reference to his own quotes (Damals hatte ich geschrieben: "Viele skandalöse Dinge, die uns alle direkt betreffen, werden von den Medien ausgespart"). The given genre framework of the diary does not prevent the blog author from combining the genre elements of emotional (Was hat sich seit 2012 geändert? Es gibt zahlreiche Verschlechterungen der Lebensqualität auf Grund von quasireligiösen Obsessionen. An den Altären von Kórona, Klima und Asylkriminalität wird eifriger geopfert, als 2012) satirical commentary (Gestern schliff Altmaier so einen honeckeresken Halbedelstein, als er von der Unumkehrbarkeit seiner Wirtschaftspolitik faselte. Es erinnert stark an den lustigen Spruch von Ochs und Esel...), as well as emotional sketching (Ich erinnere mich gerne an einen Herbstabend, als meine Freundin mit mir über das Ende der Breschjeffzeit rätselte und über die Lockerungen danach. Als wir unsere Flasche ausgetrunken hatten, war es 22:30 und der Sprecher der Tagesthemen begann seine Moderation: "Guten Abend, die erste Nachricht kommt heute aus Moskau, Seit einer Viertelstunde wird im Fernsehen getragene Musik gespielt, das deutet auf den Tod eines hohen Funktionärs hin..." Es gibt also Hoffnung) in his post. In addition, the post includes some elements of analytics and forecast. (Es ist dieses Mal schwieriger den Endpunkt der Verirrung zu prognostizieren, als vor 30 Jahren, weil die internationalen Kräfteverhältnisse wesentlich komplexer sind).

Considering linguistic means, the text is rich in political (das Regime, der Diktatur, der Nationalsozialismus, der Sozialismus) and economic (die Wirtschaftspolitik, der Wohlstand) terms, evaluative vocabulary (faseln, abgefahrenen, widerlichen, die dümmliche Phrase), metaphors (der Endpunkt der Verirrung, die Altäre von Kórona), periphrases (die finstere Physikerin, die irrlichternde Dr. Merkel), emphatic expressions (Die Legitimation der Bundesrepublik war das Wirtschaftswunder. Die Zeit ist vorbei. Scholz braucht jetzt "überraschenderweise" doch zusätzliches Steuergeld für seine Bazooka.), phraseological units (das Goldene Kalb, läuft immer noch als Laus über die Leber), nonce words (der Merkelismus), and rhetorical questions (Was hat sich seit 2012 geändert?). The text has many facts, analogies, and hints which encourage the reader to reflect and initiate a protest reaction in relation to the problem raised. The analyzed post is addressed, first of all, to the mass addressee - readers of the blog - and performs a 
convening function and is also addressed to political opponents and government representatives who are mentioned in the text in a negative and ironic manner.

\subsection{Polydiscourse and polygenre nature of Russian blogs}

Russian political blogs also demonstrate discursive hybridity, which is manifested in the combination of Internet discourse with elements of political, legal, business, artistic, and conversational discourses. The revealed polydiscourse nature correlates with the genre and stylistic hybridization of political blogs $[8,12]$ combining such genres as post, remark, appeal, open letter, and survey (for example, the remark posted on the Ekho Moskvy information platform «Гражданская инициатива зарегистрирована») [Gudkov D.]. The texts of posts often combine features of formal and business and colloquial and substandard speech, for example: Так что уважаемый Дмитрий Сергеевич и уважаемьй Кремль, мы тоже очень обеспокоены ситуацией и выражаем глубокую озабоченность, но вам глубоко пофигу. Это провал Вася. Или как? Пишите мне Здесь! [Gorny A.]. The above text is an ironically colored incentive for the mass recipient (blog readers) to reproduce the ratings given by the blog author. In the given extract, the effect of irony is created due to the contrast between clichéd phrases typical of business speech (уважаемьии Дмитрий Сергеевич, обеспокоены ситуачией и выражаем глубокую озабоченность), and slang vocabulary (пофигу), colloquial phrases (Это провал Вася. Или как?) as well as deliberately incorrect use of formal business clichés when using metonymic address (уважаемый Кремль). Convening power of the post is set by the vector:

the author's assessment of the situation $\rightarrow$ encouraging an emotional response within the framework of the proposed assessment $\rightarrow$ attracting supporters from among his readers $\rightarrow$ "strengthening" the assessment by the mass addressee - co-addresser. "strengthening" the assessment by the mass addressee-co-addressee. In the given extract, the blogger formally addresses the authorities, but the target recipient is a mass reader. Let's look at another example which demonstrates the formation of convening power due to creolization of the text of the post, the author of which is a popular Russian blogger I. Varlamov: "Протесты в Беларуси. На улииы снова никто не вышел" (https://varlamov.ru/4061327.html). This post is a verbal series and a visual series (photos, videos) contrasting with each other and ensure the implementation of the convening power function:

caption - В Минске и других городах Беларуси люди снова не вышли на протест.

photo - a lot of people protesting in the streets;

caption - Размеренная жизнь. Велопешеходный переход.

photo - military equipment and soldiers at the crossing.

The post ends with a brief author's conclusion which removes misunderstanding of the captions: Белорусские власти продолжают пытаться всех убедить, что протест сдулся, ... вот только это не соответствует действительности (varlamov.ru). In neneral, basing on a comprehensive analysis carried out, we can say that the Russian political blogs are characterized by the presence of a socially significant reason, focus to attract supporters, public opinion shaping, and a combination of formal and spoken language.

\section{Political blogs of Russia and Germany: subject and communicative-personal dimensions}

The political blog content analysis in Germany and Russia made it possible to identify areas which bloggers perceive as threatening and causing a critical reaction. Figure 1 shows the problems framed by blog authors, which indicates the proactivity of protest when 
"communication replacing reality creates a problem and turns a circumstance into a social factor, the realism of which is provided by the threat index" [8]. In Fig. 1, light hatching marks the problem areas common to the German and Russian blogs, and dark hatching marks the problem areas that differ in German and Russian content. Social issues, economy, government, and international events are highlighted as common problem areas in the German and Russian blogs, which indicates their significance and suggests a certain objectivity of cohesion between problem-threat framing and the reality in any society.
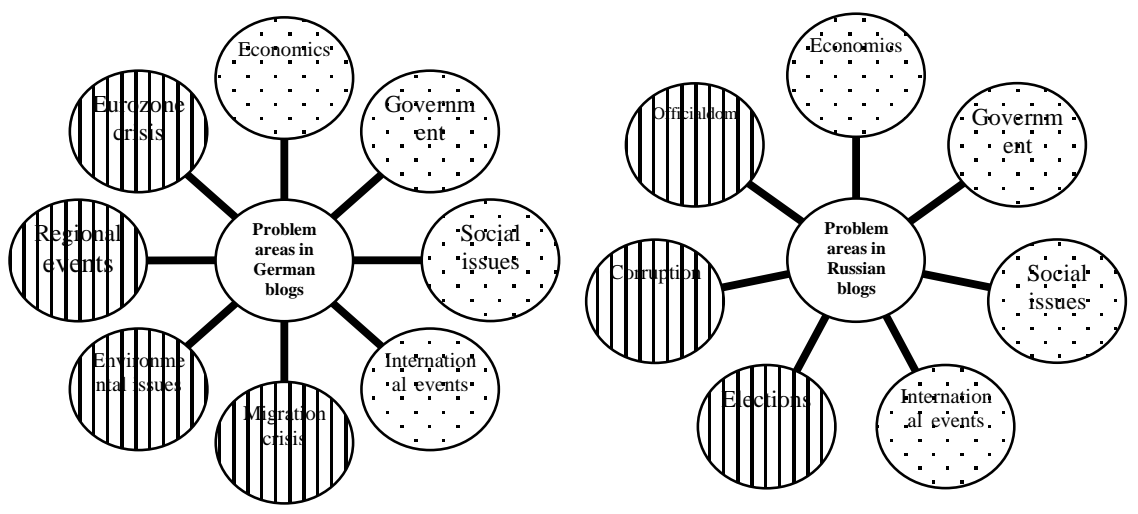

Fig. 1. Problem areas in German and Russian blogs.

The Eurozone crisis, various regional events, environmental issues, and the migration crisis are among the problem areas which are typical for German blogs. Political bloggers in Russia are interested in issues of elections, corruption, and officialdom in addition to overlapping problem areas. Environmental issues, which are actively discussed in German blogs, have not yet received the status of an independent topic with the threat index in the Russian political blogosphere and are often included in the problems of the "power officials" sphere. At the same time, the analysis of the strategy and tactical organization of German and Russian political blogs shows that their linguopragmatics coincide. German and Russian blogs are characterized by the strategies to justify the "problem" status and provide an assessment supported / not supported by facts, which ensure the selected problem areas framing. These strategies are implemented by a set of specific tactics (Fig. 2.)
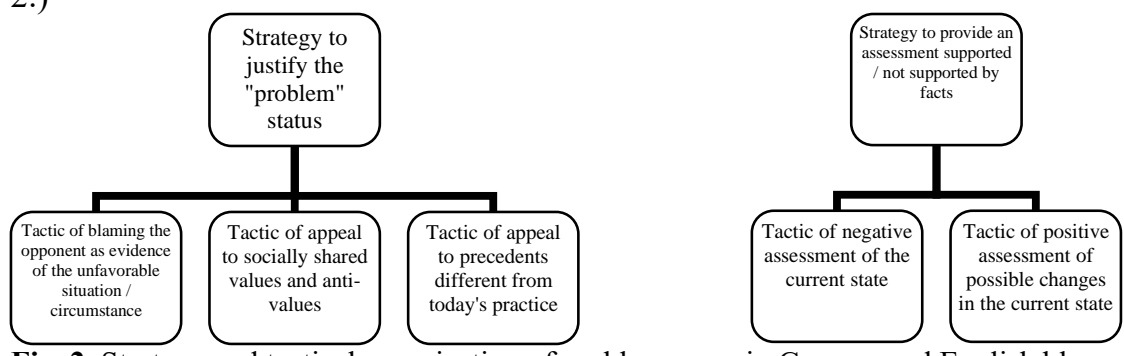

Fig. 2. Strategy and tactical organization of problem areas in German and English blogs.

So, we can say that the strategy and tactical organization of the blogs studied does not differ in the languages under consideration. 


\section{German and Russian political blogs as a product of mediatization of politics and personality}

As is known, politics mediatization involves shifting of political values and aspects from the reality as it is to virtual reality. The constructed virtual media reality "not only affects the ongoing political processes replacing true reality but also actively forms it" [9]. Let us illustrate this situation with a fragment from Varlamov's post where the addresser tries to cause sensory image of one of the politicians in the minds of the mass addressee as well as to form a strong sense in the readers that this situation is real: He «nomupaem свои кровавые лапки и ждёт, когда у соперника сдадут нервы. Он хочет, чтобы оппозиция ударила первой, думая, что получит моральное право навсегда с ней расквитаться. Но оппозищия не бьёт и не ведётся на его провокации. (https://varlamov.ru/4071964.html). At the same time, the media addresser's desire to significantly enhance the influence of the text through stylistic means, discursive and genre hybridization, and maximum use of the possibilities of its hypertext structure is of particular importance.

The mediatization of a blogger's personality is reflected in the selectivity of their position as an observer when political agenda is shaped. Thus, I. Varlamov's blog is mainly focused on covering the activities of the United Russia party. Here are just a few post titles which show the author's assessment of the party: «Не голосуешь за «Единую Россию»не пьешь воду»; "Осторожно! Этот пост полон "Единой Россией», "Гопота из «Единой России» нападает на людей». The mediatization of personality is characterized by a simplifying reduction of social reality depending on the interests of the mass addressee, unambiguous assessment of events and processes, and the dominance of emotional argumentation.

Mediatization of the blogger's personality happens through social virtualization of Selfresources, animation of one's Self, and formation of "Self-worship", for example: Ich kann mich nicht darüber freuen, wenn Konzerne Profite erzielen indem sie die Allgemeinheit schädigen. (28.04.2020 17:17. Sahra Wagenknecht. https://www.facebook.com). The complex nature of the addresser and addressee should be considered a feature of the blogger's mediatization [12].

In addition, the so-called Net-thinking, which is characterized by multi-vector, nonlinearity, volume, is a manifestation of mediation in public spheres and mediatization of the personality [4]. The features of Net-thinking are reflected in blogs as a discursive practice, namely: in referring to external resources, in combining the presentation of information in photo, video, and audio formats; in the predominance of a combination of compositional elements over the development of logical argumentation; in various trajectories of individual awareness and large numbers of information processing algorithms.

\section{Conclusion}

The system and communicative analysis allowed us to establish common and specific features of the German and Russian blogs as a relevant protest practice.

Common features include polydiscourse nature, genre hybridization, a single vector of convening power, and the same type of strategy and tactical organization of the problem areas with the "threat" index.

The German and Russian blogs are characterized by signs of mediatization of politics and the blogger's personality. The mediatization of politics is manifested in the replacement of true reality with media reality through stylistic means, discursive and genre hybridization, and the maximum use of the blog hypertext structure. The mediatization of 
the blogger's personality is reflected in the selectivity of their position as an observer when political agenda is shaped, in the desire to reduce reality depending on the interests of the mass addressee, to offer the audience an unambiguous assessment of events and processes by means of predominantly emotional argumentation.

Mediatization of the blogger's personality is also carried out through social virtualization of Self-resources and active use of the potential of the so-called Net-thinking.

The specific features include a variety of elements of different types of discourses which ensure polydiscourse nature of protest practices as well as a diverse set of topics for discussion marked with the "threat" index.

\section{Acknowledgments}

This work was supported by the Russian Foundation for Basic Research, grant No. 20-01200193.

This paper was financially supported by the Russian Foundation for Basic Research, grant No. 20-012-22046.

\section{References}

1. A. Jungherr, P. Jürgens, Zeitschrift für Parlamentsfragen, 1 (2011)

2. A. Kavanaugh et al., Information polity, 22, 2-3 (2017)

3. E. B. Pavlova, Nauchnyi dialog, 1 (2019)

4. G. Small, G. Vorgan, iBrain: Surviving the Technological Alteration of the Modern Mind (New York, Harper-Collins, 2009)

5. J. Berg, International journal of e-politics, 8, 1 (2017)

6. K. Lundby (Ed). Mediatization of Communication (Berlin, De Gruyter Mouton, 2014)

7. L.F. Luna-Reyes, Information polity, 22. 2-3 (2017)

8. L.N. Rebrina, N.L. Shamne, Systemic-Communicative Dimensions of Modern Protest (based on German-Language Online Petitions), Nauchnyi dialog, 3 (2020)

9. L.V. Kazimirchik, Political sciences. Theory and practice of social development, 11 (2014)

10. Liu, K. Helen, Information polity, 22, 2-3 (2017)

11. M. Deutsch, P. T. Coleman, E. C. Marcus, The Handbook of Conflict Resolution: Theory and Practice (San Francisco, Jossey-Bass Publishers, 2006)

12. M. V. Milovanova, E. V. Terentyeva, Nauchnyi dialog, 6 (2020)

13. P.K. Goncharov, Social and humanitarian knowledge, 2 (2018)

14. R. Fisher, W. Ury, B. Patton Getting to Yes: Negotiating Agreement Without Giving (New York, Penguin Books, 2011)

15. S.V. Paulov, Scientific Bulletin of Belgorod State University, 2 (42), 6 (2008)

16. Z. Oniszczuk, Studiów Medioznawczych, 4, 47 (2011) 